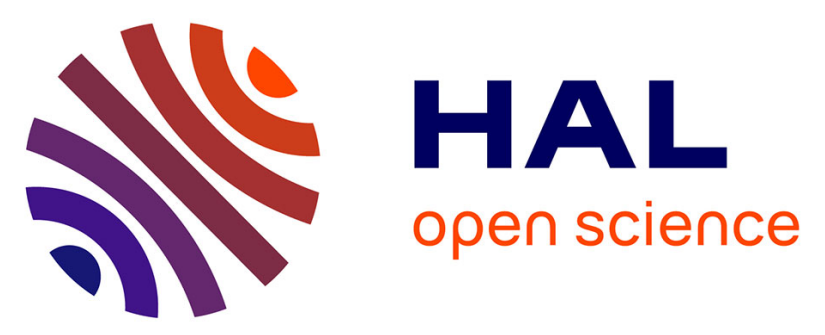

\title{
In vivo evaluation of CYP2A6 and xanthine oxidase enzyme activities in the Serbian population
}

Natasa Djordjevic, Juan Antonio Carrillo, Guillermo Gervasini, Slobodan Jankovic, Eleni Aklillu

\section{- To cite this version:}

Natasa Djordjevic, Juan Antonio Carrillo, Guillermo Gervasini, Slobodan Jankovic, Eleni Aklillu. In vivo evaluation of CYP2A6 and xanthine oxidase enzyme activities in the Serbian population. European Journal of Clinical Pharmacology, 2010, 66 (6), pp.571-578. 10.1007/s00228-010-0785-6 . hal-00612986

\section{HAL Id: hal-00612986 https://hal.science/hal-00612986}

Submitted on 2 Aug 2011

HAL is a multi-disciplinary open access archive for the deposit and dissemination of scientific research documents, whether they are published or not. The documents may come from teaching and research institutions in France or abroad, or from public or private research centers.
L'archive ouverte pluridisciplinaire HAL, est destinée au dépôt et à la diffusion de documents scientifiques de niveau recherche, publiés ou non, émanant des établissements d'enseignement et de recherche français ou étrangers, des laboratoires publics ou privés. 


\title{
In vivo evaluation of CYP2A6 and xanthine oxidase enzyme activities in the Serbian population
}

\author{
Natasa Djordjevic • Juan Antonio Carrillo • \\ Guillermo Gervasini • Slobodan Jankovic • Eleni Aklillu
}

Received: 13 October 2009/Accepted: 11 January 2010/Published online: 13 February 2010

(C) Springer-Verlag 2010

\begin{abstract}
Purpose The main aim of the study was to investigate the distribution of cytochrome P450 2A6 (CYP2A6) and xanthine oxidase (XO) enzyme activities in the Serbian population. Secondly, we tested the influence of genetics (CYP2A6 polymorphism), sex, and cigarette smoking on both enzymes.

Methods One hundred forty healthy Serbian volunteers were genotyped for common CYP2A6 alleles. In 100 of them, CYP2A6 and XO activities were determined by the urinary $17 \mathrm{U} / 17 \mathrm{X}$ and $1 \mathrm{U} /(1 \mathrm{U}+1 \mathrm{X})$ ratios, respectively, after oral administration of $100 \mathrm{mg}$ caffeine as a probe.

Results A 21-fold variation in the $17 \mathrm{U} / 17 \mathrm{X}$ ratio was observed (range: $0.49-10.28$, mean $=1.65,95 \%$ CI: 1.49 1.83). The urinary $1 \mathrm{U} /(1 \mathrm{U}+1 \mathrm{X})$ ratios displayed four-fold variation, ranging from 0.17 to 0.71 (mean $=0.43,95 \% \mathrm{CI}$ : $0.41-0.45)$. CYP $2 A 6$ alleles $* 1 A, * 1 B 1, * 9, * 4$ and $* 1 B 1 \times 2$ were found with frequencies of $0.579,0.307,0.082,0.029$, and 0.004 respectively. $C Y P 2 A 6^{*} 5$ was not detected. CYP2A6 genotype influenced interindividual variability in
\end{abstract}

N. Djordjevic $\cdot$ E. Aklillu $(\bowtie)$

Division of Clinical Pharmacology, Department of Laboratory Medicine,

Karolinska University Hospital Huddinge, Karolinska Institutet, 14186 Stockholm, Sweden

e-mail: Eleni.Aklillu@ki.se

\section{N. Djordjevic $\cdot$ S. Jankovic}

Department of Pharmacology and Toxicology, Medical Faculty, University of Kragujevac,

34000 Kragujevac, Serbia

\section{J. A. Carrillo · G. Gervasini}

Division of Clinical Pharmacology, Department of Medical

and Surgical Therapeutics, Medical School,

University of Extremadura,

06071 Badajoz, Spain
CYP2A6 enzyme activity $(P=0.04)$. Cigarette smoking inhibited CYP2A6 enzyme activity $(P=0.02)$, but had no effect on activity of XO $(P=0.16)$. There was no significant difference between men and women in terms of CYP2A6 or XO activity.

Conclusions Serbs displayed interindividual variations in CYP2A6 activity. CYP2A6 genotype and cigarette smoking, but not sex, influenced CYP2A6 enzyme activity. Unimodal distribution of $\mathrm{XO}$ enzyme activity in Serbs implies the absence of subjects with low enzyme activity in this population. XO activity is not influenced by sex or cigarette smoking.

Keywords CYP2A6 Xanthine oxidase $\cdot$ Serbian . Phenotype $\cdot$ Caffeine $\cdot$ Genotype

\section{Introduction}

Cytochrome P450 2A6 enzyme (CYP2A6) is an important hepatic enzyme involved in the activation of many procarcinogens and the clearance of a number of pharmaceuticals $[1,2]$. Wide interindividual variations in CYP2A6 activity, well documented both in vitro and in vivo [3, 4], have been associated with metabolism of several drugs, diseases, or environmental factors $[1,2,5]$. Previous studies, using nicotine and cotinine as probes, showed an inhibitory effect of cigarette smoking on CYP2A6 enzyme activity $[5,6]$. Sex differences have been observed as well $[4,7-10]$, but the findings were not always consistent [11, 12]. Nevertheless, the major cause for the observed variability in enzyme activity seems to be genetic polymorphisms of the CYP2A6 gene [1].

Xanthine oxidase (XO) is a multifunctional enzyme responsible for oxidation processes of a wide range of 
substrates, including a number of endogenous compounds and several clinically important drugs [11, 13-17]. Previous studies, using radiochemical assay [13] or caffeine test [11, 14, 18, 19], showed that XO activity differs among individuals. Known functional genetic variations in the $\mathrm{XO}$ gene are rare [20]. Although environmental factors seem to be responsible for the described variability $[15,17$, 19], it is generally accepted that cigarette smoking does not affect XO activity [11, 19, 21]. Sex differences have been extensively studied as well, but with contradictory results $[11,13,14,19,21]$.

Both CYP2A6 and XO participate in the metabolism of caffeine: CYP2A6 is the major enzyme responsible for the conversion of caffeine metabolite paraxanthine $(1,7-$ dimethylxanthine or 17X) into 1,7-dimethyluric acid (17U), while XO participates in conversion of paraxanthine metabolite 1-methylxanthine (1X) to 1-methyluric acid (1U) [12]. Because of its pharmacokinetics and noninvasive properties, caffeine as a probe drug represents the safest method for evaluation of CYP2A6 and XO in humans [11, 18, 22, 23].

Ethnicity is an important demographic variable affecting interindividual variability in drug metabolism and response, and a number of differences among populations have already been reported [14, 24, 25]. CYP2A6 exhibits marked interethnic differences [26], but data on its activity in Eastern European populations are scarce [11]. On the other hand, little is known about the interethnic variations in XO activity.

The Serbian population belongs to the South Slavonic group of Indo-European peoples, with its ethnic location in the central and western part of the Balkan Peninsula. There are around 6.2 million Serbs living in Serbia at present (http://webrzs.statserb.sr.gov.yu). Recently, we reported significant differences in CYP1A2 enzyme activity between Serbs and Swedes, although both populations are of Caucasian origin [14, 24, 25]. Nevertheless, data on activity of other drug metabolizing enzymes in Serbs are still lacking. Thus, in the present study we investigated CYP2A6 and XO enzyme activities in Serbs, using caffeine as a probe drug. In addition, we examined the correlation of CYP2A6 genetic polymorphism with CYP2A6 activity, as well as the influence of sex and cigarette smoking on both CYP2A6 and XO enzyme activities.

\section{Materials and methods}

Study subjects One hundred forty unrelated healthy Serbian volunteers (72 men and 68 women) participated in the CYP2A6 genotype analyses; of these 100 participated in the caffeine phenotyping. The subjects who were phenotyped included 55 men and 45 women 18-46 years old, with a median age of 27 years and a median weight of $73.8 \mathrm{~kg}$ (range 43.0-120.1 kg). Among them, 21 men and 17 women were smokers, smoking 2-40 cigarettes per day. None of the subjects had chronic or acute use of any medications, and none of the female participants were pregnant, breastfeeding, or using oral contraceptives. All subjects gave written informed consent for both phenotyping and genotyping analysis.

Study participants abstained from consuming caffeinecontaining food or beverage for at least $24 \mathrm{~h}$ prior to and throughout the study period. After voiding the bladder, each subject received a $100 \mathrm{mg}$ oral dose of caffeine (Koffein Recip; Recip, Årsta, Sweden), and urine was collected for $8 \mathrm{~h}$ in a plastic can without any additives. Volume and $\mathrm{pH}$ of collected urine were measured, and 20-ml aliquots were stored. In addition, a 20-ml venous blood sample was collected into EDTA-containing Vacutainer tubes (Sarstedt, Nümbrecht, Germany). All samples were frozen at $-80^{\circ} \mathrm{C}$ and packed on dry ice. Blood samples were sent to Karolinska University Hospital-Huddinge, Sweden, for genotype analyses. Urine samples were sent to Extremadura University, Badajoz, Spain, for phenotyping. The study was approved by the ethics committees at the Medical Faculty, University of Kragujevac, Serbia, and at Karolinska Institutet, Stockholm, Sweden. The study was conducted in accordance with the Declaration of Helsinki and its subsequent revisions.

CYP2A6 genotyping DNA was extracted from the wholeblood samples using QIAamp DNA Mini Kit (QIAGEN, Hilden, Germany). All PCR reactions were performed on GeneAmp PCR System 2700 (Applied Biosystems, Foster City, CA), using the primers purchased from Invitrogen, Carlsbad, CA. All other reagents used for PCR amplification were from Roche Applied Science, Mannheim, Germany. Genotyping for gene deletion $\left(C Y P 2 A 6^{*} 4\right)$, gene duplication $\left(C Y P 2 A 6^{*} 1 x 2\right), 1436 \mathrm{G}>\mathrm{T}\left(C Y P 2 A 6^{*} 5\right)$, and gene conversion in the $3^{\prime}$ region $\left(C Y P 2 A 6^{*} 1 B 1\right)$ was carried out using the allele-specific PCR methods presented in Table $1[2,27]$. For the detection of $C Y P 2 A 6^{*} 9(-48 \mathrm{~T}>$ $\mathrm{G})$, we performed a two-step allele-specific PCR. PCR I was used to amplify a 335-bp-long region of CYP2A6 exon 2, using the primers $2 \mathrm{~A} 6 \mathrm{~F} 7$ and $2 \mathrm{~A} 6$ ex1R. The reaction mixture contained $1 \mu \mathrm{l}$ genomic DNA, $0.25 \mu \mathrm{M}$ of each primer, $0.8 \mathrm{mM}$ of dNTPs, $1.5 \mathrm{mM} \mathrm{MgCl} 2$, and $0.625 \mathrm{U}$ of AmpliTaq DNA polymerase, and was carried out in $1 \times$ PCR buffer II, in a total volume of $25 \mu \mathrm{l}$. The initial denaturation was performed at $95^{\circ} \mathrm{C}$ for $1 \mathrm{~min}$; followed by 35 cycles of denaturation at $95^{\circ} \mathrm{C}$ for $15 \mathrm{~s}$, annealing at $56^{\circ} \mathrm{C}$ for $20 \mathrm{~s}$, and extension at $72^{\circ} \mathrm{C}$ for $90 \mathrm{~s}$; and with a final extension at $72^{\circ} \mathrm{C}$ for $7 \mathrm{~min}$. In PCR II, forward primers TATA $16 \mathrm{wt}$ or TATA $16 \mathrm{mut}$ with reverse primer 2A6 ex1R were used for amplification of 243-bp-long 
Table 1 SNPs and primers used in genotyping of CYP2A6 gene by allele-specific PCR method

\begin{tabular}{|c|c|c|c|c|c|}
\hline Nucleotide change & Allele variation & Reaction & Primer name & Sequence $5^{\prime}$ to $3^{\prime}$ & PCR product (bp) \\
\hline \multirow[t]{3}{*}{$C Y P 2 A 6^{*} 1 B 1$} & \multirow[t]{3}{*}{$\begin{array}{l}\text { Gene conversion } \\
\text { in } 3^{\prime} \text { region }\end{array}$} & PCR I & $\begin{array}{l}\text { 2A6 ex8F2 } \\
2 \mathrm{~A} 6 \mathrm{R} 5\end{array}$ & $\begin{array}{l}\text { CTCCAACCCCCAGGACTTCAA } \\
\text { GCACTTATGTTTTGTGAGACAT } \\
\text { CAGAGACA }\end{array}$ & 1300 \\
\hline & & \multirow[t]{2}{*}{ PCR II } & $\begin{array}{l}2 \mathrm{~A} 6^{*} 1 \mathrm{Bwt} \\
2 \mathrm{~A} 6^{*} 1 \mathrm{Bmut}\end{array}$ & $\begin{array}{l}\text { ACTGGGGGCAGGATGGC } \\
\text { AATGGGGGGAAGATGCG }\end{array}$ & \multirow[t]{2}{*}{300} \\
\hline & & & 2A6 R2 & TCTTAGCTGCGCCCCTCTCC & \\
\hline \multirow[t]{3}{*}{$C Y P 2 A 6^{*} 4$} & \multirow[t]{3}{*}{ Gene deletion } & PCR I & $\begin{array}{l}2 \mathrm{~A} \text { ex } 7 \mathrm{~F} \\
2 \mathrm{~A} 6 \mathrm{R} 5\end{array}$ & $\begin{array}{l}\text { GGCCAACATGCCCTACATG } \\
\text { GCACTTATGTTTTGTGAGACAT } \\
\text { CAGAGACA }\end{array}$ & 1,967 \\
\hline & & \multirow[t]{2}{*}{ PCR II } & $\begin{array}{l}2 \mathrm{~A} 6 \text { ex8F } \\
2 \mathrm{~A} 7 \mathrm{ex} 8 \mathrm{~F}\end{array}$ & $\begin{array}{l}\text { CACTTCCTGAATGAG } \\
\text { CATTTCCTGGATGAC }\end{array}$ & \multirow[t]{2}{*}{1,180} \\
\hline & & & 2A6 R7 & TCTTAGCTGCGCCCCTCTCC & \\
\hline \multirow[t]{3}{*}{$C Y P 2 A 6^{*} 5$} & \multirow[t]{3}{*}{$1436 \mathrm{G}>\mathrm{T}$} & PCR I & $\begin{array}{l}\text { 2A6 ex8F2 } \\
2 \mathrm{~A} 6 \mathrm{R} 5\end{array}$ & $\begin{array}{l}\text { CTCCAACCCCCAGGACTTCAA } \\
\text { GCACTTATGTTTTGTGAGACAT } \\
\text { CAGAGACA }\end{array}$ & 1,300 \\
\hline & & \multirow[t]{2}{*}{ PCR II } & $\begin{array}{l}2 \mathrm{~A} 6 * 5 \mathrm{wt} \\
2 \mathrm{~A} 6 * 5 \mathrm{mut}\end{array}$ & $\begin{array}{l}\text { CCCCAAACACGTGGG } \\
\text { CCCCAAACACGTGGT }\end{array}$ & \multirow[t]{2}{*}{152} \\
\hline & & & 2A6 R2 & TCTTAGCTGCGCCCCTCTCC & \\
\hline \multirow[t]{3}{*}{$C Y P 2 A 6^{*} 9$} & \multirow[t]{3}{*}{$-48 \mathrm{~T}>\mathrm{G}$} & PCR I & $\begin{array}{l}2 \mathrm{~A} 6 \mathrm{~F} 7 \\
2 \mathrm{~A} 6 \mathrm{ex} 1 \mathrm{R}\end{array}$ & $\begin{array}{l}\text { TGGCTGTGTCCCAAGCTAGGCA } \\
\text { CTTCATGAGGGAGTTGTACATC }\end{array}$ & 335 \\
\hline & & \multirow[t]{2}{*}{ PCR II } & $\begin{array}{l}\text { TATA } 16 \mathrm{wt} \\
\text { TATA } 16 \mathrm{mut}\end{array}$ & $\begin{array}{l}\text { CTTTTTCAGGCAGTAT } \\
\text { CTTTTTCAGGCAGTAG }\end{array}$ & \multirow[t]{2}{*}{243} \\
\hline & & & $2 \mathrm{~A} 6$ ex1R & CTTCATGAGGGAGTTGTACATC & \\
\hline \multirow[t]{2}{*}{$C Y P 2 A 6^{*} 1 \times 2$} & \multirow[t]{2}{*}{ Gene duplication } & \multirow[t]{2}{*}{ One-step PCR } & $\begin{array}{l}2 \mathrm{~A} 7 \text { ex8F } \\
2 \mathrm{~A} 6 \mathrm{ex} 8 \mathrm{~F}\end{array}$ & $\begin{array}{l}\text { CATTTCCTGGATGAC } \\
\text { CACTTCCTGAATGAG }\end{array}$ & \multirow[t]{2}{*}{1,258} \\
\hline & & & 2A7 R1 & $\begin{array}{l}\text { GCACTTATGTTTTGTGAGACAT } \\
\text { GAGATAGA }\end{array}$ & \\
\hline
\end{tabular}

product. The $25-\mu \mathrm{l}$ mixtures contained $0.25 \mu \mathrm{M}$ of one of the forward primers, $0.25 \mu \mathrm{M}$ of reverse primer, $0.4 \mathrm{mM}$ dNTPs, $1.3 \mathrm{mM} \mathrm{MgCl}_{2}, 0.625 \mathrm{U}$ of AmpliTaq DNA polymerase, and $1 \mu \mathrm{l}$ of PCR I product in a $1 \times$ PCR buffer II. The reaction conditions were as follows: initial denaturation at $95^{\circ} \mathrm{C}$ for $1 \mathrm{~min} ; 15$ cycles of denaturation at $95^{\circ} \mathrm{C}$ for $15 \mathrm{~s}$, annealing at $54^{\circ} \mathrm{C}$ for $20 \mathrm{~s}$, and extension at $72^{\circ} \mathrm{C}$ for $45 \mathrm{~s}$; and final extension at $72^{\circ} \mathrm{C}$ for $7 \mathrm{~min}$. Products of PCR I and PCR II were detected by gel electrophoresis on a $1.2 \%$ agarose gel stained with ethidium bromide.

Caffeine phenotyping The caffeine urinary test was performed according to the method described by Carrillo et al. [28], using high-performance liquid chromatography (HPLC) to determine molar concentrations of caffeine metabolites 17X (1,7-dimethylxanthine or paraxanthine), $17 \mathrm{U}$ (1,7-dimethyluric acid), 1X (1-methylxanthine), and $1 \mathrm{U}$ (1-methyluric acid) in urine samples. System Gold Microbore HPLC with 32 Karat Software (Beckman Instruments, Madrid, Spain) was used to process the HPLC data. Enzyme activity of CYP2A6 was assessed by the ratio of $17 \mathrm{U} / 17 \mathrm{X}[4]$, and $\mathrm{XO}$ activity by the $1 \mathrm{U} /(1 \mathrm{U}+1 \mathrm{X})$ ratio [19].
Statistical analysis Statistical analyses were performed with Statistica, version 7.1 (StatSoft, Tulsa, OK, USA). For all statistical procedures, $P<0.05$ was considered as significant. The $95 \%$ confidence interval calculations were according to the modified Wald method. Chi-squared test was used to compare observed with expected allele frequencies (HardyWeinberg equilibrium). The $17 \mathrm{U} / 17 \mathrm{X}$ ratio was $\log$ transformed before statistical analyses. The 1U/1X and 1U/ $(1 \mathrm{U}+1 \mathrm{X})$ ratios were correlated using Pearson analysis. Consistency of the data with the normal distribution was assessed by Shapiro-Wilk test. The main effects ANOVA model followed by post-hoc analyses (the Fisher LSD test) was used to assess the effects of genotype, sex, and smoking on CYP2A6 and XO activities. The correlation between CYP2A6 activity and number of cigarettes smoked per day was tested using regression analysis.

\section{Results}

CYP2A6 enzyme activity was estimated by the urinary $17 \mathrm{U} / 17 \mathrm{X}$ ratio in 100 healthy volunteers after administra- 
tion of $100 \mathrm{mg}$ caffeine as a probe. A 21-fold variation in the $17 \mathrm{U} / 17 \mathrm{X}$ ratio was observed (range $0.49-10.28$, mean= 1.65, 95\% CI: $1.49-1.83$ ), and the values displayed lognormal distribution (Fig. 1a; $\mathrm{W}=0.99, P=0.58$ ). Comparison of $17 \mathrm{U} / 17 \mathrm{X}$ ratio regarding the smoking habit indicated significantly lower enzyme activity among smokers (Fig. 1b, c; $P=0.022 ; 95 \%$ CI for the mean difference $1.035-1.637$ ). There were no differences in the $17 \mathrm{U} / 17 \mathrm{X}$ ratio between men and women in the whole group or between nonsmokers and smokers (Table 2, 8.2\% power). Using the allele-specific PCR, 140 healthy Serbian volunteers were genotyped for the following CYP2A6 variant alleles: gene deletion

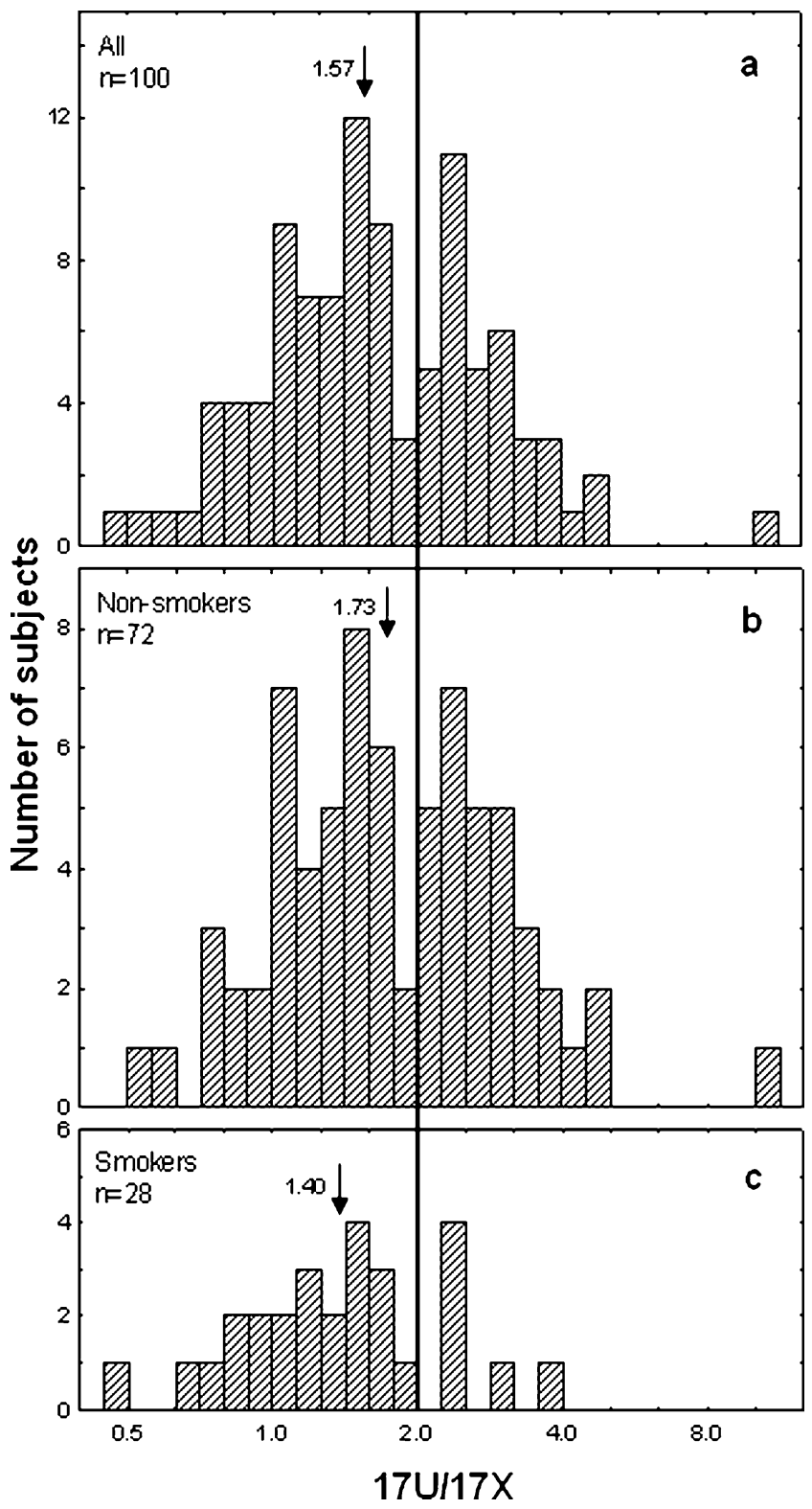

Fig. 1 The frequency distributions of the log-transformed 17U/17X ratio in Serbs. The arrows indicate the medians and the adjacent numbers are antilog values. The vertical line is shown at an arbitrary antilog value of 2.0 as reference
$\left(C Y P 2 A 6^{*} 4\right)$, gene duplication $\left(C Y P 2 A 6^{*} 1 \times 2\right)$, gene conversion in $3^{\prime}$ region $\left(C Y P 2 A 6^{*} 1 B 1\right)$, the promoter SNP-48T $>\mathrm{G}$ $\left(C Y P 2 A 6^{*} 9\right)$, and $1436 \mathrm{G}>\mathrm{T}\left(C Y P 2 A 6^{*} 5\right)$. The frequencies of CYP2A6 variant alleles and genotype combinations in the Serbian population are presented in Table 3. All the observed CYP2A6 genotype frequencies were according to HardyWeinberg equilibrium $\left(\chi^{2}=1.3, P>0.05\right)$.

For the analysis of CYP2A6 genotype-phenotype correlations, subjects were assigned to one of three genotype groups: group A (extensive metabolizers:* $1 A *{ }^{*} 1 A, * 1 A /$ $* 1 B 1, * 1 A * 1 B 1 \times 2$, and $* 1 B 1 * 1 B 1$ ), group B (intermediate metabolizers: $* 1 A * 4, * 1 A * 9, * 1 B 1 * 4$, and $* 1 B 1 * 9)$ and group C (poor metabolizers: *4/9 and *9/9). Assignments were performed according to the expected effects of specific CYP2A6 genotypes on enzyme activity, based on a number of functional $(* 1 A, * 1 B 1$, or $* 1 B 1 \times 2)$ or nonfunctional alleles $(* 9$ and $* 4)$. Frequency distribution of the $17 \mathrm{U} / 17 \mathrm{X}$ ratio between the different genotype groups is displayed in Fig. 2. Comparison of mean $17 \mathrm{U} / 17 \mathrm{X}$ ratios showed significant CYP2A6 genotype-phenotype association, the activity being higher in subjects having both functional alleles (Table 4; $P=0.04$ ). Further dividing the groups according to the cigarette smoking habit showed a similar tendency in nonsmokers $(P=0.06)$ but not in smokers $(P=$ $0.14,39.6 \%$ power). In subjects carrying both functional alleles, the mean $17 \mathrm{U} / 17 \mathrm{X}$ ratio remained significantly lower $(P=0.04)$ among smokers $(n=24$, mean $=1.46,95 \%$ CI: $1.22-1.75)$ than nonsmokers $(n=58$, mean $=1.89,95 \% \mathrm{CI}$ : 1.64-2.17). Among smokers, regression analysis indicated no significant correlation between $17 \mathrm{U} / 17 \mathrm{X}$ ratio and number of cigarettes smoked per day $\left(r^{2}=0.04, P=0.29\right)$.

$\mathrm{XO}$ activity was estimated in 100 healthy volunteers after oral administration of $100 \mathrm{mg}$ caffeine as a probe. The urinary $1 \mathrm{U} / 1 \mathrm{X}$ and $1 \mathrm{U} /(1 \mathrm{U}+1 \mathrm{X})$ ratios were highly correlated $(r=0.99)$, suggesting that either of the ratios can be used as an index, and the phenotype was determined on the basis of the latter. The frequency distribution of the $1 \mathrm{U} /(1 \mathrm{U}+1 \mathrm{X})$ ratio is shown in Fig. 3. The individual metabolic ratios displayed fourfold variation, ranging from 0.17 to 0.71 (mean $=0.43,95 \% \mathrm{CI}: 0.41-0.45$ ), and the values were normally distributed $(\mathrm{W}=0.99, P=0.89)$. There were no differences in $1 \mathrm{U} /(1 \mathrm{U}+1 \mathrm{X})$ ratio between men and women ( $P=0.17$; men: $n=55$, mean $=0.46,95 \%$ CI: 0.43 0.48 ; women: $n=45$, mean $=0.43,95 \%$ CI: $0.40-0.46$ ), or between nonsmokers and smokers $(P=0.14$; nonsmokers: $n=72$, mean $=0.44,95 \%$ CI: $0.41-0.46$; smokers: $n=28$, mean $=0.47,95 \%$ CI: $0.43-0.51$ ).

\section{Discussion}

In the present study, we examined CYP2A6 and XO enzyme activities in the Serbian population. Furthermore, 
Table 2 Comparisons of mean 17U/17X ratios between Serbian men and women, based on the smoking habit

\begin{tabular}{|c|c|c|c|c|c|}
\hline & \multicolumn{2}{|l|}{ Men } & \multicolumn{2}{|l|}{ Women } & \multirow[t]{2}{*}{$P(95 \% \mathrm{CI}$ of the mean difference $)$} \\
\hline & Number & Mean $(95 \% \mathrm{CI})$ & Number & Mean $(95 \% \mathrm{CI})$ & \\
\hline All & 55 & $1.65(1.43,1.90)$ & 45 & $1.65(1.41,1.95)$ & $\begin{array}{l}0.97(-0.09,0.09) \\
0.93(0.02,40.84)\end{array}$ \\
\hline Nonsmokers & 39 & $1.78(1.50,2.12)$ & 33 & $1.77(1.46,2.16)$ & $0.98(-0.11,0.11)$ \\
\hline Smokers & 16 & $1.36(1.06,1.75)$ & 12 & $1.37(1.01,1.85)$ & $\begin{array}{l}0.99(-0.16,0.15) \\
0.93(0.02,40.84)\end{array}$ \\
\hline
\end{tabular}

we investigated CYP2A6 genotype-phenotype correlation, as well as the influence of sex and cigarette smoking on CYP2A6 and XO enzyme activities. The results designated CYP2A6 genotype and cigarette smoking as determinants of interindividual variability in CYP2A6 enzyme activity. To the best of our knowledge, this is the first study to investigate CYP2A6 and XO enzyme activity, as well as CYP2A6 genetic polymorphism, in Serbs, and to report the influence of cigarette smoking on enzyme activity using caffeine as a probe drug while controlling for the effect of CYP2A6 genotype.

CYP2A6 plays an important role in the activation of many procarcinogens, including aflatoxin $\mathrm{B}_{1}, N$-nitrosodiethylamine, and 1,3-butadiene, as well as in the clearance of

Table 3 Allele and genotype frequencies of CYP2A6 gene in the Serbian population

\begin{tabular}{|c|c|c|}
\hline & Observed frequency & $95 \% \mathrm{CI}$ \\
\hline \multicolumn{3}{|l|}{ Allele $^{\mathrm{a}}$} \\
\hline$C Y P 2 A 6^{*} 1 A$ & $0.579(162 / 280)$ & $0.520,0.635$ \\
\hline$C Y P 2 A 6^{*} 1 B 1$ & $0.307(86 / 280)$ & $0.256,0.364$ \\
\hline$C Y P 2 A 6^{*} 1 B 1 \times 2$ & $0.004(1 / 280)$ & $0.000,0.022$ \\
\hline$C Y P 2 A 6^{*} 4$ & $0.029(8 / 280)$ & $0.014,0.057$ \\
\hline$C Y P 2 A 6^{*} 5$ & $0.000(0 / 280)$ & $0.000,0.017$ \\
\hline$C Y P 2 A 6^{*} 9$ & $0.082(23 / 280)$ & $0.055,0.121$ \\
\hline \multicolumn{3}{|l|}{ Genotype } \\
\hline$C Y P 2 A 6^{*} 1 A / * 1 A$ & $0.336(47 / 140)$ & $0.263,0.418$ \\
\hline$C Y P 2 A 6^{*} 1 A / * 1 B 1$ & $0.336(47 / 140)$ & $0.263,0.418$ \\
\hline$C Y P 2 A 6^{*} 1 A / * 1 B 1 \times 2$ & $0.007(1 / 140)$ & $0.000,0.044$ \\
\hline$C Y P 2 A 6^{*} 1 A / * 4$ & $0.036(5 / 140)$ & $0.013,0.084$ \\
\hline$C Y P 2 A 6^{*} 1 A / 9$ & $0.107(15 / 140)$ & $0.065,0.171$ \\
\hline$C Y P 2 A 6^{*} 1 B 1 / * 1 B 1$ & $0.114(16 / 140)$ & $0.071,0.179$ \\
\hline$C Y P 2 A 6^{*} 1 B 1 / * 4$ & $0.014(2 / 140)$ & $0.001,0.055$ \\
\hline$C Y P 2 A 6^{*} 1 B 1 / * 9$ & $0.036(5 / 140)$ & $0.013,0.084$ \\
\hline$C Y P 2 A 6^{*} 4 / 9$ & $0.007(1 / 140)$ & $0.000,0.044$ \\
\hline$C Y P 2 A 6^{* 9} / * 9$ & $0.007(1 / 140)$ & $0.000,0.044$ \\
\hline
\end{tabular}

${ }^{\text {a } C Y P} 2 A 6^{*} 1 A$ Wild type, $C Y P 2 A 6^{*} 1 B 1$ gene conversion in $3 '$ region, $C Y P 2 A 6^{*} 1 B 1 \times 2$ gene conversion in $3^{\prime}$ region, gene duplication, $C Y P 2 A 6^{*} 4$ gene deletion, $C Y P 2 A 6^{*} 51436 \mathrm{G}>\mathrm{T}, C Y P 2 A 6^{*} 9-48 \mathrm{~T}>\mathrm{G}$ some pharmaceuticals [1, 29]. As observed in other populations [4], log-transformed 17U/17X ratios in Serbs were normally distributed. The level of interindividual variations in CYP2A6 activity found in Serbs corresponds to Caucasian data [11], while larger variability up to more than 100 -fold has been reported in other populations $[4,30$, 31]. Disease conditions and other modifying factors may

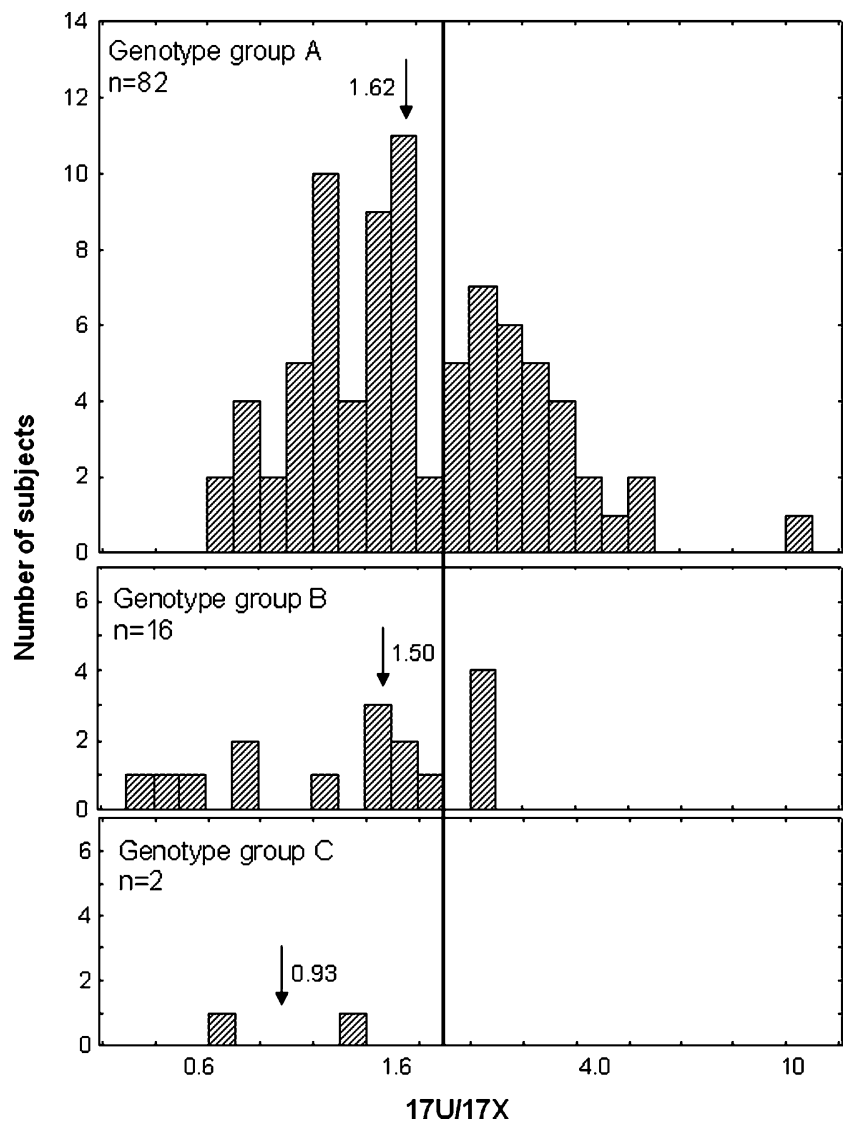

Fig. 2 Comparison of the frequency distribution of log-transformed $17 \mathrm{U} / 17 \mathrm{X}$ ratio in different genotype groups of Serbs. The arrows indicate the medians and the adjacent numbers are antilog values. The vertical line is shown at an arbitrary antilog value of 2.0 as reference. Genotype group A: $C Y P 2 A 6^{*} 1 A / * 1 A, C Y P 2 A 6^{*} 1 A / * 1 B 1$, $C Y P 2 A 6^{*} 1 A{ }^{*} 1 B 1 \times 2, C Y P 2 A 6^{*} 1 B 1 / * 1 B 1$; genotype group $B$ : $C Y P 2 A 6^{*} 1 A * 4, C Y P 2 A 6^{*} 1 A * 9, C Y P 2 A 6^{*} 1 B 1 / 44, C Y P 2 A 6^{*} 1 B 1 /$ $* 9$; genotype group c: $C Y P 2 A 6^{*} 4 * 9, C Y P 2 A 6^{*} 9 / 9$ 
Table 4 Comparisons of mean 17U/17X ratios among different genotype groups ${ }^{\mathrm{a}}$ in Serbs, based on the smoking habit

\begin{tabular}{|c|c|c|c|c|c|c|}
\hline & \multicolumn{2}{|l|}{ Group A } & \multicolumn{2}{|l|}{ Group B } & \multicolumn{2}{|l|}{ Group C } \\
\hline & Number & Mean $(95 \%$ CI $)$ & Number & Mean $(95 \% \mathrm{CI})$ & Number & Mean $(95 \% \mathrm{CI})$ \\
\hline All & 82 & $1.75(1.56-1.96)$ & 16 & $1.31(0.97-1.76)$ & 2 & $0.93(0.02-40.84)$ \\
\hline Nonsmokers & 58 & $1.89(1.64-2.17)$ & 14 & $1.39(1.02-1.88)$ & 0 & - \\
\hline Smokers & 24 & $1.46(1.22-1.75)$ & 2 & $0.87(0.00-1209.65)$ & 2 & $0.93(0.02-40.84)$ \\
\hline
\end{tabular}

${ }^{a}$ Group A: subjects carrying two functional alleles $\left(C Y P 2 A 6^{*} 1 A{ }^{*} 1 A, C Y P 2 A 6^{*} 1 A * 1 B 1, C Y P 2 A 6^{*} 1 A / * 1 B 1 \times 2\right.$, and $\left.C Y P 2 A 6^{*} 1 B 1 / * 1 B 1\right)$; group B: subjects carrying one functional allele $\left(C Y P 2 A 6^{*} 1 A * 4, C Y P 2 A 6^{*} 1 A * 9, C Y P 2 A 6^{*} 1 B 1 / * 4\right.$, and $\left.C Y P 2 A 6^{*} 1 B 1 / * 9\right)$; group C: subjects carrying no functional alleles $\left(C Y P 2 A 6^{*} 4 * 9\right.$ and $C Y P 2 A 6^{*} 9 / * 9$

partly account for the observed wider interindividual variations in CYP2A6 activity [32]. Besides other nongenetic factors, CYP2A6 genetic variation has been suggested to cause the interindividual variability in enzyme activity [33]. Carriers of gene deletion allele $C Y P 2 A 6^{*} 4$ completely lack the CYP2A6 enzyme [2], while CYP2A6*5 and CYP $2 A 6^{*} 9$ both result in decreased enzymatic activity [1]. On the other hand, CYP2A6 activity in subjects having $C Y P 2 A 6$ duplication, corresponding to the presence of three copies of the gene, was reported to be 1.4-fold higher than in wild-type homozygous [26, 27]. A gene conversion with $C Y P 2 A 7$ in the $3^{\prime}$-untranslated region (3'-UTR), described as $C Y P 2 A 6^{*} 1 B 1$ [34], is reported to be associated with either full [5, 34] or even increased [9] enzyme activity. In Serbs, the frequencies of described CYP $2 A 6$ genetic variations, as well as of corresponding alleles and genotypes, were comparable with the results previously published for other Caucasians [27, 35, 36].

To investigate the influence of CYP2A6 genotype on enzyme activity, subjects were grouped based on the number of functional variant alleles and the expected effect on phenotype [3]. Comparison of CYP2A6 enzyme activity

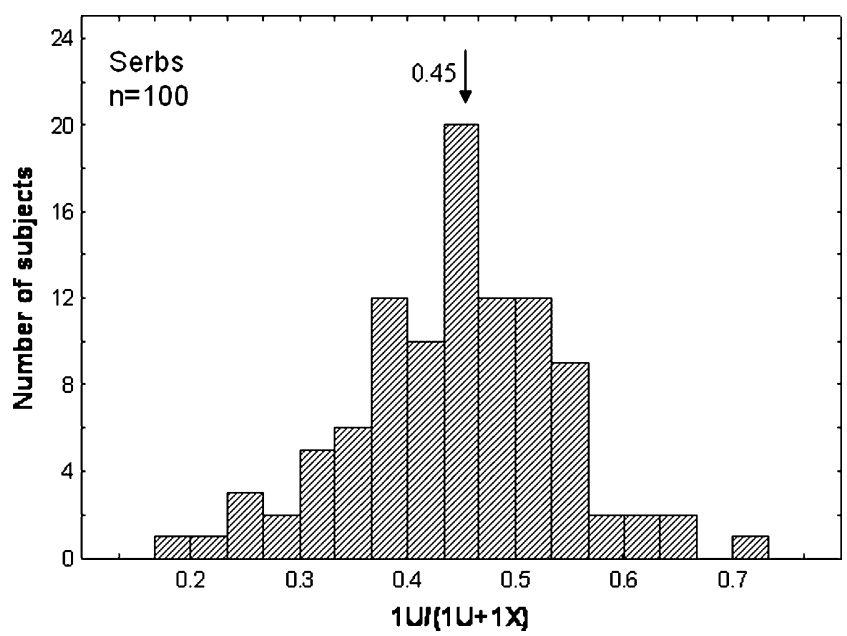

Fig. 3 The frequency distribution of the $1 U /(1 U+1 X)$ ratio in Serbs. The arrow indicates the median and the adjacent number is the antilog value among the different genotype groups showed significant differences. As expected, subjects homozygous for the functional alleles displayed higher enzyme activity than heterozygous subjects, while the lowest enzyme activity was observed in subjects homozygous for defective alleles. We further investigated genotype-phenotype correlation based on the cigarette smoking habit. In nonsmokers, CYP2A6 activity still tended to be higher among extensive metabolizers. However, we were not able to show the same effect in smokers due to the low number of subjects and hence sample power in this group.

Interestingly, in addition to $C Y P 2 A 6$ genetic polymorphism, we observed significantly lower $17 \mathrm{U} / 17 \mathrm{X}$ ratio in smokers compared to nonsmokers. It is known that cigarette smoking increases $17 \mathrm{X}$ formation by CYP1A2 induction [37-39]. In the present study, we showed that 17U/17X ratio, depicting CYP2A6 activity, was decreased in cigarette smokers. If metabolism of $17 \mathrm{X}$ to $17 \mathrm{U}$ were highly saturable, we could assume that the reduction in the $17 \mathrm{U} / 17 \mathrm{X}$ ratio in smokers was due to increased formation of $17 \mathrm{X}$. However, as metabolism of $17 \mathrm{X}$ to $17 \mathrm{U}$ is not saturable in physiological conditions [40, 41], it is highly unlikely that CYP1A2 induction affects $17 \mathrm{U} / 17 \mathrm{X}$ ratio in smokers. On the other hand, it has been suggested that CYP1A2 catalyzes metabolism of $17 \mathrm{X}$ to $17 \mathrm{U}$ to a minor extent [39]. The involvement of CYP1A2 in the formation of $17 \mathrm{U}$ from $17 \mathrm{X}$ is concentration dependent. At a lower concentration $(0.1 \mathrm{mM})$ that may reflect the in vivo conditions, CYP2A6 selectively catalyzes the conversion of $17 \mathrm{X}$ to $17 \mathrm{U}$ [4]. Both in vitro and in vivo investigations demonstrated that CYP2A6 is the principal enzyme in the formation of $17 \mathrm{U}$ from $17 \mathrm{X}$ in humans [3]. In the present study, we observed a decreased $17 \mathrm{U} / 17 \mathrm{X}$ ratio in cigarette smokers, indicating that CYP1A2 does not have a considerable role in $17 \mathrm{X}$ to $17 \mathrm{U}$ hydroxylation and hence cigarette smoking does influence CYP2A6 activity in Serbs. Since we observed significant genotype-phenotype correlation in the whole group, we further analyzed the effect of smoking habit on enzyme activity controlling for the effect of genotype. Among subjects carrying both functional alleles, significantly lower enzyme activity was 
observed in smokers than in nonsmokers. In contrast, previous phenotyping studies using caffeine as a probe drug did not find influence of smoking status on CYP2A6 activity $[4,11,12]$. Thus, to the best of our knowledge, this is the first report of smoking-mediated inhibition of $17 \mathrm{U}$ formation from 17X in smokers. During the study period, subjects refrained from drinking coffee and other caffeinecontaining beverages, but not from smoking. It is well known that nicotine is almost exclusively metabolized by the CYP2A6 enzyme [42]. Therefore, competitive inhibition by nicotine present in the cigarette smoke is likely to be responsible for the observed lower CYP2A6 enzyme activity. This finding might have clinical implications in patients treated with drugs metabolized by CYP2A6, such as halothane, valproic acid, and disulfiram [1,29].

Most of the previous studies observed sex differences in CYP2A6 activity [4, 7-10]. Benowitz et al. [7], using plasma trans-3'-hydroxycotinine/cotinine ratio, reported faster nicotine metabolism in premenopausal (but not postmenopausal) women compared to men. At the same time, women taking oral contraceptives metabolized nicotine faster than those not taking oral contraceptives, suggesting the effect of sex hormones on CYP2A6 activity. Nevertheless, other studies reported higher $17 \mathrm{U} / 17 \mathrm{X}$ ratios [4], as well as nicotine and cotinine clearances [10], in women compared to men regardless of oral contraceptive use. In the present study, women did not use oral contraceptives. Controlling for the effects of smoking, we did not detect any difference in CYP2A6 activity between men and women. Yet, this could be attributed to the small sample size. Similar to our result, some other groups also did not observe any sex difference using the urinary $17 \mathrm{U} / 17 \mathrm{X}$ ratio [11] or $17 \mathrm{U} /(17 \mathrm{U}+17 \mathrm{X}+1 \mathrm{U}+1 \mathrm{X}+\mathrm{AFMU})$ ratio [12] as indices. Apparently, the influence of sex on CYP2A6 activity remains controversial, and future studies with more participants and higher sample power are needed to resolve this issue.

Xanthine oxidase is involved in a number of constitutional reactions of both physiological and pathological significance [17]. Furthermore, this enzyme participates in the metabolism of several clinically important drugs, such as acyclovir, mercaptopurine, azathioprine, methotrexate, doxorubicin, daunomycin, and mitomycin $C$ [16]. Therefore, the variation in $\mathrm{XO}$ activity carries a potential for both lack of therapeutic effect and adverse drug reactions in treating seriously ill patients.

Several different populations have been investigated in terms of XO activity, using caffeine as a probe and either 1U/ $1 \mathrm{X}[14,22,43]$ or $1 \mathrm{U} /(1 \mathrm{U}+1 \mathrm{X})$ urinary metabolic ratio $[11$, $18,19,44]$. Some of the studies reported bimodal distribution of XO activity, suggesting the presence of poor metabolizers ranging from $4 \%$ of the population in Spaniards and Ethiopians [18, 19] up to $11 \%$ in Japanese [44].
However, in other populations, such as Danish [22] or Greek [11], XO activity appeared to be unimodally distributed. Our study clearly showed normal and unimodal distribution of XO activity, implying population homogeneity and the absence of Serbian subjects with low enzyme activity.

Because of the rarity of functional genetic variations in the XO gene [20], sex and cigarette smoking have been widely investigated as a possible determinants of $\mathrm{XO}$ activity. Most of the previous studies did not observe any correlation between sex and enzyme activity [19, 21, 22, $43,44]$. Opposite observations were presented by Relling et al. [14] and Guerciolini et al. [13], who reported higher and lower enzyme activity in women, respectively. On the other hand, it is generally accepted that cigarette smoking does not affect XO activity [19, 22, 43, 44]. In the present study, we did not detect any effect of sex or cigarette smoking on XO enzyme activity in Serbs. The results suggest that, in treating Serbian patients with drugs metabolized by xanthine oxidase, neither sex nor smoking habit needs to be considered as an important factor for dose adjustments.

In conclusion, Serbs display large interindividual variations in CYP2A6 activity. Lower CYP2A6 activity in smokers could be due to competitive inhibition of CYP2A6 by nicotine during cigarette smoking. CYP2A6 genotype, but not sex, influenced CYP2A6 enzyme activity. Unimodal distribution of XO activity in Serbs implies the absence of subjects with low enzyme activity in this population. XO activity was not influenced by sex or cigarette smoking.

Acknowledgments The authors would like to thank all volunteers who participated in the study. We are very grateful to Lilleba Bohman for technical support in the laboratory. The study was financially supported by the Swedish Research Council, Medicine, 3902; the Medical Faculty, University of Kragujevac, Republic of Serbia, JP 1/05; the Swedish Institute; Plan Nacional de Investigación Científica, Desarrollo e Innovación Tecnológica (I+D+I), Instituto de Salud Carlos III, Subdirección General de Evaluación y Fomento de la Investigación, PI071152; and Ayudas para la consolidación y apoyo a grupos de investigación de Extremadura, GRU09015 (Orden de 17 de diciembre de 2008, DOE 5 de enero de 2009). The authors report no conflicts of interest. The authors alone are responsible for the content and writing of the paper.

\section{References}

1. Oscarson M (2001) Genetic polymorphisms in the cytochrome P450 2A6 (CYP2A6) gene: implications for interindividual differences in nicotine metabolism. Drug Metab Dispos 29:91-95

2. Oscarson M, McLellan RA, Gullsten H et al (1999) Characterisation and PCR-based detection of a CYP2A6 gene deletion found at a high frequency in a Chinese population. FEBS Lett 448:105-110

3. Kimura M, Yamazaki H, Fujieda M et al (2005) CYP2A6 is a principal enzyme involved in hydroxylation of 1, 7-dimethylxanthine, a main caffeine metabolite, in humans. Drug Metab Dispos 33:13611366 
4. Nowell S, Sweeney C, Hammons G et al (2002) CYP2A6 activity determined by caffeine phenotyping: association with colorectal cancer risk. Cancer Epidemiol Biomarkers Prev 11:377-383

5. Hukkanen J, Jacob P III, Benowitz NL (2005) Metabolism and disposition kinetics of nicotine. Pharmacol Rev 57:79-115

6. Benowitz NL, Jacob P III (2000) Effects of cigarette smoking and carbon monoxide on nicotine and cotinine metabolism. Clin Pharmacol Ther 67:653-659

7. Mwenifumbo JC, Sellers EM, Tyndale RF (2007) Nicotine metabolism and CYP2A6 activity in a population of black African descent: impact of gender and light smoking. Drug Alcohol Depen 89:24-33

8. Nakajima M, Fukami T, Yamanaka H et al (2006) Comprehensive evaluation of variability in nicotine metabolism and CYP2A6 polymorphic alleles in four ethnic populations. Clin Pharmacol Ther 80:282-297

9. Johnstone E, Benowitz N, Cargill A et al (2006) Determinants of the rate of nicotine metabolism and effects on smoking behavior. Clin Pharmacol Ther 80:319-330

10. Benowitz NL, Lessov-Schlaggar CN, Swan GE, Jacob P III (2006) Female sex and oral contraceptive use accelerate nicotine metabolism. Clin Pharmacol Ther 79:480-488

11. Begas E, Kouvaras E, Tsakalof A et al (2007) In vivo evaluation of CYP1A2, CYP2A6, NAT-2 and xanthine oxidase activities in a Greek population sample by the RP-HPLC monitoring of caffeine metabolic ratios. Biomed Chromatogr 21:190-200

12. Krul C, Hageman G (1998) Analysis of urinary caffeine metabolites to assess biotransformation enzyme activities by reversed-phase high-performance liquid chromatography. J Chromatogr B Biomed Sci Appl 709:27-34

13. Guerciolini R, Szumlanski C, Weinshilboum RM (1991) Human liver xanthine oxidase: nature and extent of individual variation. Clin Pharmacol Ther 50:663-672

14. Relling MV, Lin JS, Ayers GD, Evans WE (1992) Racial and gender differences in N-acetyltransferase, xanthine oxidase, and CYP1A2 activities. Clin Pharmacol Ther 52:643-658

15. Garattini E, Mendel R, Romao MJ et al (2003) Mammalian molybdoflavoenzymes, an expanding family of proteins: structure, genetics, regulation, function and pathophysiology. Biochem J 372:15-32

16. Pritsos CA (2000) Cellular distribution, metabolism and regulation of the xanthine oxidoreductase enzyme system. Chem Biol Interact 129:195-208

17. Harrison R (2002) Structure and function of xanthine oxidoreductase: where are we now? Free Radic Biol Med 33:774-797

18. Carrillo JA, Benitez J (1994) Caffeine metabolism in a healthy Spanish population: N-acetylator phenotype and oxidation pathways. Clin Pharmacol Ther 55:293-304

19. Aklillu E, Carrillo JA, Makonnen E et al (2003) Xanthine oxidase activity is influenced by environmental factors in Ethiopians. Eur J Clin Pharmacol 59:533-536

20. Kudo M, Moteki T, Sasaki T et al (2008) Functional characterization of human xanthine oxidase allelic variants. Pharmacogenet Genomics 18:243-251

21. Kalow W, Tang BK (1991) Use of caffeine metabolite ratios to explore CYP1A2 and xanthine oxidase activities. Clin Pharmacol Ther 50:508-519

22. Rasmussen BB, Brosen K (1996) Determination of urinary metabolites of caffeine for the assessment of cytochrome P4501A2, xanthine oxidase, and N-acetyltransferase activity in humans. Ther Drug Monit 18:254-262

23. Jetter A, Kinzig M, Rodamer M et al (2009) Phenotyping of Nacetyltransferase type 2 and xanthine oxidase with caffeine: when should urine samples be collected? Eur J Clin Pharmacol 65 (4):411-417

24. Ghotbi R, Christensen M, Roh HK et al (2007) Comparisons of CYP1A2 genetic polymorphisms, enzyme activity and the genotype-phenotype relationship in Swedes and Koreans. Eur J Clin Pharmacol 63:537-546

25. Djordjevic N, Ghotbi R, Bertilsson L et al (2008) Induction of CYP1A2 by heavy coffee consumption in Serbs and Swedes. Eur J Clin Pharmacol 64:381-385

26. Fukami T, Nakajima M, Yamanaka $H$ et al (2007) A novel duplication type of CYP2A6 gene in African-American population. Drug Metab Dispos 35:515-520

27. Rao Y, Hoffmann E, Zia M et al (2000) Duplications and defects in the CYP2A6 gene: identification, genotyping, and in vivo effects on smoking. Mol Pharmacol 58:747-755

28. Carrillo JA, Christensen M, Ramos SI et al (2000) Evaluation of caffeine as an in vivo probe for CYP1A2 using measurements in plasma, saliva, and urine. Ther Drug Monit 22:409-417

29. Yoshida R, Nakajima M, Watanabe $Y$ et al (2002) Genetic polymorphisms in human CYP2A6 gene causing impaired nicotine metabolism. Br J Clin Pharmacol 54:511-517

30. Maurice M, Emiliani S, Dalet-Beluche I et al (1991) Isolation and characterization of a cytochrome P450 of the IIA subfamily from human liver microsomes. Eur J Biochem 200:511-517

31. Shimada T, Yamazaki H, Guengerich FP (1996) Ethnic-related differences in coumarin 7-hydroxylation activities catalyzed by cytochrome P4502A6 in liver microsomes of Japanese and Caucasian populations. Xenobiotica 26:395-403

32. Pelkonen O, Rautio A, Raunio H, Pasanen M (2000) CYP2A6: a human coumarin 7-hydroxylase. Toxicology 144:139-147

33. Vasconcelos GM, Struchiner CJ, Suarez-Kurtz G (2005) CYP2A6 genetic polymorphisms and correlation with smoking status in Brazilians. Pharmacogenomics J 5:42-48

34. Tyndale RF, Sellers EM (2002) Genetic variation in CYP2A6mediated nicotine metabolism alters smoking behavior. Ther Drug Monit 24:163-171

35. Oscarson M, McLellan RA, Gullsten H et al (1999) Identification and characterisation of novel polymorphisms in the CYP2A locus: implications for nicotine metabolism. FEBS Lett 460:321-327

36. Gambier N, Batt A-M, Marie B et al (2005) Association of $C Y P 2 A 6^{*} 1 B$ genetic variant with the amount of smoking in French adults from the Stanislas cohort. Pharmacogenom J 5:271275

37. Parsons WD, Neims AH (1978) Effect of smoking on caffeine clearance. Clin Pharmacol Ther 24:40-45

38. Djordjevic N (2008) Pharmacogenetics of drug metabolizing enzymes CYP1A2 and CYP2A6 in Serbian population. In Edition Kragujevac: University of Kragujevac>

39. Hakooz NM (2009) Caffeine metabolic ratios for the in vivo evaluation of CYP1A2, N-acetyltransferase 2, xanthine oxidase and CYP2A6 enzymatic activities. Curr Drug Metab 10:329-338

40. Campbell ME, Grant DM, Inaba T, Kalow W (1987) Biotransformation of caffeine, paraxanthine, theophylline, and theobromine by polycyclic aromatic hydrocarbon-inducible cytochrome (s) P-450 in human liver microsomes. Drug Metab Dispos 15:237-249

41. Grant DM, Campbell ME, Tang BK, Kalow W (1987) Biotransformation of caffeine by microsomes from human liver. Kinetics and inhibition studies. Biochem Pharmacol 36:1251-1260

42. Benowitz NL, Swan GE, Jacob P III et al (2006) CYP2A6 genotype and the metabolism and disposition kinetics of nicotine. Clin Pharmacol Ther 80:457-467

43. Chung WG, Kang JH, Park CS et al (2000) Effect of age and smoking on in vivo CYP1A2, flavin-containing monooxygenase, and xanthine oxidase activities in Koreans: determination by caffeine metabolism. Clin Pharmacol Ther 67:258-266

44. Saruwatari J, Nakagawa K, Shindo J et al (2002) A population phenotyping study of three drug-metabolizing enzymes in Kyushu, Japan, with use of the caffeine test. Clin Pharmacol Ther 72:200-208 